\title{
El LIBRO de GRACIÁN COMO DISCURSO POLíTICO EN LA CASTILLA DE JUAN II (1405-1454)
}

The Libro de Gracián as political discourse in the reign of John II of Castile (1405-1454)

\author{
Roque Sampedro López* \\ roquesampedro@gmail.com
}

RESUMEN: En este artículo se pretenden explorar algunas de las formas mediante las que se construye un discurso político en el Libro de Gracián, un relato de viajes anónimo y ficticio de la primera mitad del siglo XV castellano. Partiendo de un breve análisis de su estructura y autoría, analizaremos las intenciones, contexto y lenguaje político de la obra. Para ello recurriremos a las perspectivas teóricas de la historia intelectual, especialmente de autores como Quentin Skinner y John G.A. Pocock. Además, también estudiaremos la construcción de una idea del príncipe, elemento central en el pensamiento político de la obra.

PALABRAS CLAVE: Discurso político, Libro de Gracián, Idea de príncipe, Juan II de Castilla.

ABSTRACT: This article aims to explore some of the ways in which a political discourse is constructed in the Libro de Gracián, an anonymous and fictional travel account from the first half of the fifteenth century in Castile. Starting from a brief analysis of its structure and authorship, we will analyse the intentions, context and political language of the work. For this we will resort to the theoretical perspectives of intellectual history, specially those of authors such as Quentin Skinner and John G.A. Pocock. In addition, we will also study the construction of an idea of the prince, a central element in the political thought of the work.

KEY WORDS: Political discourse, Libro de Gracián, Idea of prince, John II of Castile.

\section{Introducción}

A lo largo de este trabajo nos proponemos analizar brevemente el pensamiento y discurso político del Libro de Gracián, ${ }^{1}$ un texto castellano anónimo escrito durante el reinado de Juan II (1405-1454). La obra, un relato de viajes, presenta un marcado discurso político y ético, crítico con el estado del reino de Castilla en su época. Así, algunos de los elementos de este discurso que analizaremos aquí, aunque sea de manera somera, serán la intención, los debates en los que de alguna manera participa, el lenguaje conceptual que se emplea o la construcción político-discursiva de la idea de príncipe.

En este sentido, recurriremos a las reflexiones teóricas de autores como Quentin Skinner, o John G.A. Pocock, quienes han propuesto una aproximación metodológica al ámbito de la historia intelectual fundamentada en la idea de contexto, intención o lenguaje político. En este sentido, la manera de abordar el texto será a través de su relación con algunos de sus

\footnotetext{
* Becario Predoctoral de la Facultad de Geografía e Historia de la Universidad de Santiago de Compostela. Departamento de Historia. Área de Historia Medieval. Especialista en pensamiento medieval.

${ }^{1}$ Esta obra, que no ha sido muy estudiada, fue editada en la revista Studia Lulliana. véanse Satorre (1980; 19811983; 1986). Si bien su editor lo denominó “Novela moral de Gracián”, siguiendo a Fernando Gómez Redondo, hemos preferido utilizar "Libro de Gracián” como título.
} 
contextos intelectuales y políticos, entendiendo que el autor anónimo, al escribir el texto, está participando activamente en la vida política y cultural de la Castilla de Juan II. Así, el discurso presenta una intencionalidad, buscando construir lo político de una forma determinada.

Nuestro objetivo, entonces, es apuntar algunas de las maneras en la que se construye lo político en el Libro de Gracián. Para ello, en primer lugar, describiremos los temas, estructura y fuentes del texto. También se analizará brevemente la cuestión de la autoría, así como el contexto político en el que se produce la obra. En un segundo apartado, nos aproximaremos a algunos de los elementos que constituyen el discurso político y ético del texto, especialmente a las intenciones a las que responde el texto, los debates en los que se ubica, y el lenguaje conceptual que emplea, en especial el derivado de la obra de Ramón Llull. Finalmente, en tercer lugar, se estudiará la construcción de una idea de príncipe en relación a la literatura política de la Baja Edad Media castellana.

\section{El Libro de Gracián: texto y autoría}

El Libro de Gracián es el foco de este artículo, por lo que cabe, empezar presentando brevemente el texto, antes de analizar los elementos de discurso y pensamiento político que se reflejan en la obra.

Escrito seguramente en el segundo cuarto del siglo $\mathrm{XV},{ }^{2}$ durante el reinado de Juan II, el texto relata el aprendizaje y viaje de Gracián. A través de las andanzas ficticias de este muchacho, se presenta un reino (Castilla) en declive, asolado por todo tipo de dificultades, entre las que destacan especialmente los abusos que experimenta el reino por parte de nobles, judíos, jueces, y especialmente por parte de los privados. La causa de esta corrupción sería el desorden moral en prelados y príncipes, cuya corrupción se presenta, como veremos, a través de un discurso y pensamiento marcadamente extraído del filósofo mallorquín Ramón Llull.

La estructura del relato es un elemento de interés a la hora de entender la construcción del discurso político del Libro de Gracián. Según Fernando Gómez Redondo (2002), la obra presentaría una estructura tripartita en la que estarían presentes varios niveles de lectura:

\footnotetext{
${ }^{2}$ Para lo relativo a la composición y datación del texto véase Satorre (1980).
} 
a) El prólogo, en el que, a través de una alegoría y su explicación, se indica el destinatario de la obra y su intención. Aquel no sería otro que el rey de Castilla (Juan II, aunque no se menciona su nombre) y la intención sería "curar" al rey de su ignorancia en relación con el reino.

b) El "adoctrinamiento estatal” que el burgués, el padre de Gracián, imparte a su hijo, que consistiría fundamentalmente en una explicación de la Creación y el orden que Dios habría dado al mundo y los deberes de prelados y príncipes, así como la corrupción que sufren al alejarse del orden divino. Esto abarcaría los primeros cuatro capítulos.

c) El viaje de Gracián, del capítulo sexto al duodécimo. En este se incluirían toda clase de abusos que Gracián contempla impotente, así como la construcción de un rey ideal en el último capítulo, una vez el protagonista sale del reino de Castilla.

Así, a grandes rasgos, el Libro de Gracián, presenta tanto argumentos teóricos (el "adoctrinamiento estatal" que el muchacho recibe de su padre) como prácticos (los abusos presenciados durante el viaje) que forman una suerte de crítica, a través de la ficción, de la situación política de Castilla durante el reinado de Juan II.

A estos elementos, habría que añadir la cuestión de las fuentes del texto. Así, el Libro de Gracián surge, en buena medida, de la lectura de la obra del filósofo mallorquín Ramón Llull (c.1232-1315/1316). En este sentido, nuestro texto es sintomático de la difusión del pensamiento Iuliano en la Castilla bajomedieval. ${ }^{3}$

Aunque nunca se lo menciona directamente, la obra luliana está presente a lo largo del texto debido a la traducción, adaptación e inserción de distintos pasajes procedentes de textos como el Llibre de meravelles, la Doctrina pueril, el Llibre de mil proverbis, el Llibre d'intenció, y el Llibre d'Evast et Blanquerna. Parte del pensamiento político del texto procede directamente de Llull, como pueda ser la definición del príncipe.

La obra luliana más importante en lo tocante a las fuentes es el Llibre de meravelles. La presencia del texto del filósofo mallorquín es especialmente palpable en los dos últimos capítulos del Libro de Gracián, ya que estos son fundamentalmente una adaptación y reorganización de diversos exempla del Llibre de meravelles, con las modificaciones apropiadas para encajarlos en el texto castellano. Además, el marco narrativo de ambas obras

\footnotetext{
${ }^{3}$ Sobre esta difusión, véase Díaz Marcilla (2012; 2015).
} 
es muy similar. El texto luliano sigue el viaje de Félix, un muchacho que, alentado por su padre, sale a recorrer el mundo. En este sentido, el personaje de Gracián parece estar inspirado en el de Félix. Con todo, el relato de Ramón Llull tiene un carácter enciclopédico, mientras que el texto castellano adquiere un tono de crítica política y moral. ${ }^{4}$

Esta perspectiva crítica no surge de la nada. Si bien no se conoce con exactitud el autor del texto ${ }^{5}$, sí hay ciertos datos que nos indican la posición política desde la que se escribe el texto. Así, se ha argumentado que el Libro de Gracián es obra de alguien próximo al arzobispo Diego de Anaya y Maldonado (1357-1437). ${ }^{6}$ Si tomamos una noción de autoría más amplia ${ }^{7}$, en la que el texto no sólo es reflejo del pensamiento y posición política del autor directo del texto, sino que también más bien producto de una configuración colectiva, en la que se pueden incluir el promotor, la imagen que el autor presenta de sí mismo, o los círculos intelectuales de los que procede la obra. Desde esta perspectiva, la figura de Diego de Anaya sería la de un autor-promotor, y el texto reflejaría su posición política.

En este sentido, los enfrentamientos de Diego de Anaya con Álvaro de Luna son un contexto importante para entender el Libro de Gracián. En efecto, la relación entre el arzobispo y el privado de Juan II es conflictiva desde 1421, cuándo Diego de Anaya apoyaba al infante Enrique de Aragón en su enfrentamiento con Álvaro de Luna. Como veremos, las críticas continuas que se hacen a lo largo de la obra a privados y nobles pueden responder a una crítica velada a la figura de don Álvaro. Así, el texto funciona como un discurso que refleja y legitima los intereses de Anaya en el contexto político del reinado de Juan II.

El Libro de Gracián funciona como un texto que incluye reflexión política y moral, el relato de un viaje, la representación de decadencia política y moral. Este relato se constituye,

\footnotetext{
${ }^{4}$ Para las fuentes, Satorre (1980).

${ }^{5}$ Además de esto, es importante destacar que Isaac Vázquez Janeiro ha sugerido un posible nombre para el texto. El autor sería, según Vázquez Janeiro, Diego Moxena de Valencia, un personaje polifacético, nacido en Valencia de León a mediados del siglo XIV, presente en el concilio de Constanza y fiel al antipapa Benedicto XIII tras su deposición. Véase Vázquez Janeira (1992).

${ }^{6}$ En relación a esto, el editor del texto, J.J. Satorre ha sostenido esta afirmación debido principalmente a: a) la pertenencia del único manuscrito conservado, el ms. 1866 de la Biblioteca Universitaria de Salamanca, al Colegio Viejo de san Bartolomé, fundado por Diego de Anaya; b) la mención del citado arzobispo en una de las obras que componen el códice manuscrito al que pertenece el Libro de Gracián, c) la crítica a los privados en el relato, que refleja el enfrentamiento entre Anaya y Álvaro de Luna. A esto habría que sumar otras cuestiones como la cercanía de Anaya a los jerónimos, que forman parte de la recepción de Llull en Castilla, y mantienen una espiritualidad muy similar a la del relato. Véase Satorre, p. 187-191, 1980). En lo tocante a la figura de Diego de Anaya véase Monsalvo (2014).

${ }^{7}$ Aunque no podemos profundizar en esto aquí, estaríamos hablando de una noción de autoría similar a la expuesta en Foucault (1977, p. 113-138)
} 
en buena medida, a través de la influencia de Ramón Llull. Asimismo, hay que tener en cuenta, a la hora de interpretar el Libro de Gracián como un discurso político, la existencia de un autorpromotor, Diego de Anaya, a cuyos intereses responde la obra, especialmente, en su enfrentamiento con Álvaro de Luna.

\section{Elementos para una definición del discurso político en el Libro de Gracián}

Una vez abordado lo relativo a las temáticas, fechas y autorías del texto, podemos pasar a definir algunas cuestiones metodológicas relativas a la idea de "discurso político". Lo político, para nosotros, designa lo relativo a la organización de la sociedad, a la distribución del poder, a las formas de gobierno o a los fines de la comunidad, entre otros aspectos. Ahora bien, una de las formas en las que se construye lo político, esto es, la distribución del poder u otros de estos elementos, es a través del discurso y del pensamiento. ${ }^{8}$ Así, el Libro de Gracián se puede interpretar como un discurso en el que están presentes una serie de ideas políticas (la monarquía, la nobleza, el poder, la justicia) y que refleja y contribuye a la construcción de lo político en su época, esto es, en el reinado de Juan II. Los conceptos de discurso y de pensamiento, sin embargo, no son totalmente transparentes, sino que es posible pensarlos de diversas maneras. En este sentido, vamos a recurrir aquí a las formulaciones de autores como Quentin Skinner o John G.A. Pocock para precisar como entendemos la noción de discurso y su funcionamiento.

Para empezar, podemos comprender un texto como el resultado de una acción. Los textos y, por tanto, los discursos no son un objeto independiente de la actividad humana, evidentemente, sino su resultado. El discurso político medieval -pensemos en el aristotelismo, el conciliarismo, o el agustinismo político- son producto de la actividad, mental y comunicativa, de distintos autores en diferentes contextos, intentando participar en debates, responder a preguntas, legitimar posiciones políticas, o promover distintas acciones. Un ejemplo serían las obras de Egidio Romano y Juan de París durante el conflicto entre Bonifacio VIII y Felipe el Hermoso de Francia, en las que se intenta responder a cuestiones relativas a la naturaleza de la autoridad papal o la relación entre el poder temporal y el poder espiritual, y, por tanto, legitimar las distintas posiciones y promover una determinada visión de lo político. ${ }^{9}$

\footnotetext{
${ }^{8}$ La idea de que lo político, o en un sentido más amplio, lo social, se constituye a través del discurso o del pensamiento admite diversos grados.

${ }^{9}$ A este respecto, véase Canning ( 2003, p. 137-148).
} 
Ahora bien, como resultado de una acción, los textos reflejan una determinada intención, o más bien, un conjunto de intenciones. Según Quentin Skinner, ${ }^{10}$ a la hora de entender las intenciones de un autor al escribir un texto, resulta conveniente distinguir entre lo que hace el texto (criticar, advertir, justificar, ordenar) y las intenciones que pueda tener un autor al escribir el texto. En este sentido, se puede hablar de ambos tipos de intenciones a la hora de entender el Libro de Gracián.

En primer lugar, el autor expresa sus intenciones desde el prólogo de la obra. A través, de una alegoría, se presenta a sí mismo como un ermitaño que, tras vivir una vida de pecado, se habría convertido tras ver "con ojos espirituales algund tanto del árbol de la divina çiençia". Siguiendo este imaginario, el destinatario del libro es el rey, y para el autor, el texto es como un fruto de dicho árbol, destinado a "curar" la ignorancia del rey respecto a su reino:

\begin{abstract}
t por la virtud del qual fructo puede ser sana una enfermedad peligrosa que viene por ygnorançia que acaesçe en algunos prínçipes, con la qual non saben muchas cosas que en sus prinçipados se fazen, que son fechas contra la voluntad de Dios t contra su justiçia, las quales, sy sopiesen, podríanlas emendar $\mathrm{t}$ han de dar a Dios cuenta dellas. $\mathrm{t}$, porque las deven saber $\mathrm{t}$ corregir con todo su poder, el qual libro es puesto a correçión de la Santa Eglesia Xristiana, por que, sy algund error en él oviere dicho, lo emiende a onra t loor de Nuestro Sennor Dios. (SATORRE, 1981-1983)
\end{abstract}

El texto pretende informar al rey de los males que padece el reino. Lo que hace el texto es informar o advertir, a través de la ficción, aunque el autor pueda tener otras intenciones a mayores, como pueda ser conseguir que don Álvaro de Luna pierda el favor del rey, si asumimos que el Libro de Gracián surge del entorno del arzobispo Diego de Anaya. Por supuesto, el texto también tiene otras funciones. Se explica qué es un príncipe y sus funciones, se critica a privados y caballeros, e incluso se legitima el tiranicidio, aunque de una manera ambivalente.

Informar, explicar, criticar o justificar son de alguna manera las funciones del discurso del texto. Ahora bien, esto no debe ser confundido con la intención del autor al escribir el texto. Estas funciones del discurso son medios en la acción del autor, y por tanto están relacionados con sus intenciones, aunque no tengan por qué coincidir. Más bien, cabría pensar, dado lo que ya se ha dicho sobre la relación entre Diego de Anaya, promotor del texto, y Álvaro de Luna, privado de Juan II, que el texto es un ataque a la figura del Condestable, a

\footnotetext{
${ }^{10}$ En relación con las aportaciones metodológicas de Quentin Skinner, véanse los ensayos recogidos en Skinner (2002).
} 
pesar de que no se lo mencione directamente. Así, a través del texto, el autor buscaría desacreditar al privado e intentaría contribuir a que este perdiera su poder. En definitiva, se trataría de una forma de promocionar las posiciones políticas de Diego de Anaya.

Esta cuestión se comprende mejor, una vez, se posiciona el texto en su contexto intelectual y político, en especial, si se entiende la obra como una contribución a los debates intelectuales de su momento (SKINNER, 2002, p.114-116). Por supuesto, en este sentido, un texto puede intentar responder a diferentes preguntas y participar en distintos debates. Lo político, al menos en su dimensión intelectual, se construye a partir de conflictos en torno a conceptos, descripciones, valoraciones o teorías que contribuyen pensar la realidad. Un conflicto intelectual de este tipo está presente durante el reinado de Juan II, especialmente en relación a la idea de tiranía, y de alguna manera en él participa el Libro de Gracián.

En este sentido, en torno a la figura de Álvaro de Luna gira todo un debate durante el reinado de Juan II, que culminará en la ejecución del privado en 1454 . El conflicto del Condestable con los infantes de Aragón y ciertos sectores de la nobleza (en los que se puede encuadrar a Diego de Anaya) no opera únicamente a nivel político o militar sino también a nivel discursivo. Así, el privado se construye como una suerte de objeto discursivo, al que se le adscriben toda una serie de características que lo definirían como un tirano y, por tanto, su acción sería ilegítima. Es acusado de exacciones ilegítimas, de apropiación del patrimonio real, de engaños o de no buscar el bien común en su gobierno, críticas similares a las que el Libro de Gracián profiere a los privados en general (NIETO SORIA, 2017). Álvaro de Luna incluso llega a ser comparado con el Anticristo (GUADALAJARA, 1990).

En este sentido, el autor del Libro de Gracián es consciente de estar participando en un debate, de estar tomando una posición política. El texto no es sólo un conjunto de consideraciones abstractas en torno a las funciones de los príncipes, privados, o una condena de la vida mundana más o menos abstracta, sino que está participando activamente en la construcción de la realidad política. En particular, está proponiendo una determinada visión de la realidad opuesta a otras. Así, desde el principio se afirma que el libro ha de ser defendido por los

sabios de la Santa Escriptura que han verdadera t firme entençión, t punnan en amar $t$ conosçer a Dios $t$ a multiplicamiento de virtudes $t$ contrastamiento de viçios $t$ pecados, que lo defiendan de los letrados $t$ de los otros omnes que han contrarias entençiones a las cosas susodichas que, con sotilezas 
diabólicas t razones non verdaderas, que acatan a este mundo t non a Dios, quieren contrastar verdad con falsos entendimientos (SATORRE, 1981-1983, p. 90).

Con todo, si bien existe una proyección política de estos debates, esto es, un conjunto de acciones y personas a las que se refieren y a las que califican, el conflicto también tiene lugar en un espacio discursivo, del que forman parte el vocabulario empleado, los formas de representar la realidad (metáforas, ficciones, razonamiento) o los elementos retóricos. En definitiva, lo que se ha llamado "lenguaje político". ${ }^{11}$ Las acciones políticas tienen lugar en contextos discursivos, de los cuáles estos lenguajes forman una parte importante. Además, los intelectuales no piensan y escriben en un vacío, sino que lo hacen por referencia a un vocabulario común, a conceptos más o menos compartidos, o en referencia a autores anteriores. Este último sería el caso del Libro de Gracián, que recurriría, a través de la traducción y adaptación de diversos pasajes de la obra de Ramón Llull, a una suerte de “lenguaje luliano" para expresar sus ideas, críticas y perspectivas. En cierto sentido, el autor de la obra es fundamentalmente un lector.

El vocabulario de Ramón Llull está presente a lo largo de todo el Libro de Gracián. Su presencia se destila fundamentalmente a través de las adaptaciones de la obra del filósofo mallorquín al texto castellano. Es ahí donde aparecen nociones lulianas como las de primera y segunda intención, una de las distinciones conceptuales acuñadas por Ramón Llull a la hora de fundamentar su pensamiento ético y, en consecuencia, político. Por ejemplo, la definición de prelado del Libro de Gracián está extraída del Llibre de intenció de Llull:

Prelado es, fijo, por entençión de regir t governar los clérigos que le son deyuso, así commo pueblo es deyuso de prínçipe. $t$ aqueste prelado deve aver la primera entençión a los clérigos t la segunda a su preladía. (SATORRE, 1981-1983, p. 98)

Se trata de distinguir el fundamento social de un determinado oficio, de la voluntad personal del individuo que ocupe este oficio. Así, se da una ordenación entre la "intenciones", por las cuales existe una finalidad para cada orden de la sociedad, quede debe anteponerse a

\footnotetext{
${ }^{11}$ Véase Pocock (2009). Aunque, según Pocock, los lenguajes políticos suelen surgir de las actividades de un grupo profesional (juristas, teólogos), es posible que también aparezcan debido a la influencia de un autor idiosincrático, que acuñe su propio vocabulario, estilo de razonamiento o temáticas particulares. Este sería el caso, en nuestra opinión, del Libro de Gracián.
} 
los deseos de sus integrantes. Y si esta jerarquía entre intenciones se subvierte, se argumenta a lo largo de la obra, el resultado es el desorden moral y la corrupción. ${ }^{12}$

Así, lo político en el Libro de Gracián se articula en un entramado de intenciones, lenguaje conceptual, y argumentaciones en los debates de su momento. En este sentido, la aproximación que realizamos aquí supone pensar la reflexión política y ética como integrada en un determinado contexto, en este caso los conflictos del reinado de Juan II, como una forma de entender como se construye el argumentario de un texto.

\section{La construcción de la idea de príncipe en el Libro de Gracián}

Uno de los temas centrales del Libro de Gracián es la construcción discursiva de una idea de "príncipe", esto es, la argumentación en torno a los deberes, funciones, limitaciones, orígenes y dinámicas de los príncipes como gobernantes de una comunidad política. Entendamos aquí el término príncipe como referido precisamente a cualquier gobernante de una comunidad, esto es, como un término que abarca a duques, reyes, emperadores y otras figuras de poder. ${ }^{13} \mathrm{~A}$ continuación, avanzaremos algunas ideas relativas a la interpretación de los pasajes de la obra (principalmente el capítulo IV, en el adoctrinamiento que recibe Gracián por parte de su padre), contextualizando el discurso de la obra en el panorama políticointelectual.

Tengamos en cuenta, que los siglos XIV y XV, en este sentido, son un período de expansión del pensamiento político, de la mano de diversos cambios del orden político medieval. ${ }^{14}$ Se trata de una época en la que abundan reflexiones sobre la naturaleza del poder, el orden adecuado de una comunidad política, o sobre la monarquía, en nuevos términos. En este sentido, abundan las reflexiones sobre la idea de príncipe, no sólo a través de disquisiciones sobre la mejor forma de gobierno, sino a través de discursos que aconsejan a los propios gobernantes acerca de qué virtudes cultivar, cuáles son las tentaciones en las que

\footnotetext{
12 Para estas cuestiones, véase Trías Mercant (1969).

${ }^{13} \mathrm{Al}$ menos, así parece entenderse en el texto: "Fijo, el prínçipe que ha la primera entençión a ser enperador o rey, duque o marqués t ha la segunda en virtudes, estonçe es, fijo, desviado de verdadera entençión " (SATORRE, 1981-1983, p. 105).

14 Tradicionalmente, se ha visto en la Baja Edad Media como el momento de origen del Estado moderno, o al menos, se ha argumentado que los desarrollos políticos bajomedievales apuntan hacia la construcción del Estado. Esta postura está articulada en Strayer (1981). Sin embargo, más recientemente se ha apuntado la posibilidad de ver la Baja Edad Media no como un período de transición entre un sistema político feudal (Plena Edad Media) y la emergencia de los Estados soberanos (Edad Moderna), sino como una época con dinámicas políticas propias. Véase al respecto Watts (2009).
} 
puede incurrir o cuál es la mejor manera de tratar a su familia y a sus allegados. Es lo que se ha venido llamando los espejos de príncipes. ${ }^{15} \mathrm{Y}$ el Libro de Gracián, de alguna manera, entronca con esta tradición literaria en su articulación de la noción de "príncipe".

Puesto que el contenido del Libro de Gracián supera lo educativo para convertirse en una representación de la corrupción del reino y una crítica de los privados, no es formalmente un espejo de príncipes. Sin embargo, resulta interesante pensarlo en el contexto de estos tratados, teniendo en cuenta la difusión de dichos textos durante la Baja Edad Media en Castilla, y el rol que juegan en la configuración de un pensamiento sobre la realeza. ${ }^{16}$ Los espejos de príncipes se pueden entender, también, como una práctica discursiva, como un tipo de texto con sus reglas propias. Se trataría de una práctica en la que la intención es presentar un modelo ideal de monarquía, con una finalidad didáctica, ética y política, con sus temas y argumentos. En este sentido, nuestra obra, en especial su capítulo IV, puede entenderse en el contexto de esta práctica discursiva, si bien, como ser argumentará, difiere de ellas en varios sentidos.

Además de este contexto cultural, más amplio, la obra tiene un contexto más próximo, el reinado de Juan II, en el que la propia idea de monarquía estaba en discusión. Esta discusión es paralela al conflicto de "monarquía frente a nobleza"17, del cuál forman parte, de alguna manera, los enfrentamientos entre Álvaro de Luna y Juan II y los infantes de Aragón. Así, se constituye un discurso político en el que la noción de "rey" (o príncipe o monarca) adquiere diversas connotaciones, matices o clarificaciones, a veces contradictorias. ${ }^{18}$ Se trata de una pugna por definir al rey y sus funciones, esto es, un conflicto discursivo en torno a la construcción de uno de los elementos fundamentales de lo político. Y en esta pugna participa el Libro de Gracián.

Partiendo de estos dos contextos, es posible analizar algunos de los elementos del pensamiento político del Libro de Gracián. En lo tocante a la literatura especular, es posible argumentar que el Libro de Gracián invierte los usos propios de esta práctica discursiva, ya

\footnotetext{
15 Véase Már Jónsson (2006, p. 153-166).

16 Véase al respecto Nogales Rincón (2006).

${ }^{17} \mathrm{La}$ idea del enfrentamiento entre la nobleza y la monarquía como una constante del orden político castellano del siglo XV no está exenta de debate. (MONSALVO ANTÓN, 2017).

${ }^{18}$ Por ejemplo, Nieto Soria (2002).
} 
que en vez de plantear directamente un modelo de rey ideal, más bien se representan la realidad de los príncipes de una manera negativa, como moralmente corrupta.

Para empezar, el texto no se desvía de la tradición de pensamiento político reflejada en los espejos de príncipes al definir la noción de príncipe:

Prinçipe, fijo, es con entençión que, con temor, tenga justiçia en su prinçipado: ca, sí commo el Santo Padre Apostólico es en el mundo por entençión que con caridad govierne t mantenga sus sometidos, así, fijo, prínçipe es por entençión que sea temido omnes henemigos de justiçia. Amable fijo, prínçipe deve aver la primera entençión a ganar mérito en su oficio por obra de fe $t$ de sperança $t$ de las otras virtudes, $t$ la segunda entençión deve aver a su oficio; más el demonio, que es contrario a la ordenaçión de las dos entençiones, tien[t]a a los prínçipes, por tal que entençión salga del ordenamiento por que es creada en omne". (SATORRE, 1981-1983, p. 104) $)^{19}$

Así, el Libro de Gracián enfatiza la idea de justicia como motivo de la existencia de los príncipes, como su función fundamental. Sin embargo, apropiándose del texto de Ramón Llull, y por tanto de su lenguaje y conceptos (primera y segunda intención), advierte contra los peligros del desorden moral en el príncipe. Esta caracterización posiblemente obedezca al tono general de la obra, crítico con la situación de Castilla y, por tanto, de alguna manera con el gobierno de Juan II, y en especial Álvaro de Luna. En este sentido, se avanza una construcción de la figura del rey enfatizando los peligros del cargo de príncipe.

De la misma manera, otro de los elementos relevantes de la noción bajomedieval de monarquía en la literatura especular castellana, la idea de que el poder del príncipe deriva del poder de Dios, se introduce en el texto para enfatizar precisamente la corrupción de los príncipes. Para el autor, los príncipes comportan incorrectamente cuando olvidan las intenciones de su cargo, se creen una suerte de dioses en la tierra y piensan que sus herencias y conquistas se deben a méritos propios, y no precisamente al poder de Dios. ${ }^{20}$ Así, el autor enfatiza la maldad de los príncipes actuales invirtiendo la noción de rey ideal que está presente en el mundo cultural en el que se mueve.

\footnotetext{
${ }^{19}$ Este pasaje está extraído del Llibre d'intenció de Ramón Llull.

20 “Antes fazen dios de sí mesmos t atribuyen a sí el querer $\mathrm{t}$ el poder de sí $\mathrm{t}$ del pueblo. $\mathrm{t}$ tienen que los reinados $\mathrm{t}$ los principados $\mathrm{t}$ los reinados $\mathrm{t}$ los omnes de ellos son suyos, $\mathrm{t}$ que pueden fazer de ellos $\mathrm{t}$ con ellos segund su voluntad, porque los conquistaron ellos o los heredaron. t piensan que, por las tales herençias t conquistas, Dios perdió su derecho t el sennorío que en los otros omnes $\mathrm{t}$ las otras cosas de los regnos ha sido creador, sostenedor $\mathrm{t}$ governador de ellos. Ca, si los prínçipes t reyes biven, por Dios han vida t son sostenidos t bivificados. t, si reinan, por Dios son en los regimientos t por tal que fagan la voluntad suya, por cuyo querer ellos son en los ofiçios" (SATORRE, 1981-1983, p. 104-105).
} 
Pongamos un último ejemplo en relación con el uso que se hace de los rasgos propios de la monarquía en la literatura castellana bajomedieval, en este caso en relación a la virtud de la liberalidad (NOGALES RINCÓN, 2006, p. 23). De nuevo el énfasis se orienta a dar una imagen negativa de los príncipes. Así, en el relato, después de que el padre de Gracián criticase que los príncipes pusieran cargas demasiado onerosas sobre el pueblo, para gastar lo recaudado en cosas sin demasiada utilidad, su hijo afirma que ha leído que los príncipes deben ser generosos, dar como Dios, da. A esto el burgués responde que lo que Dios da es suyo y no se lo quita a nadie, mientras que el príncipe debe dar a quién "faze algund serviçio de que se sigue en pro de el regno", pero no debe "ponerle muchedunbre de dineros que aya sobre el pueblo t para sienpre" (SATORRE, 1981-1983, p. 109). De nuevo, el énfasis no es tanto el modelo ideal de príncipe, sino más bien mostrar como la realidad de los príncipes existentes se encuentra muy lejos de dicho modelo.

En este sentido, se podría decir que, de alguna forma, el Libro de Gracián asume que los posibles lectores de su texto conocen los modelos habituales de los espejos de príncipes, y "subvierte" dicha práctica discursiva al invertir el ideal de príncipe que estos presentan, a partir de la presentación de una realidad que se encuentra lejos de dichos ideales. Con todo, el discurso sí se mantiene dentro de los valores de esta tradición, no llegando a proponer, al menos explícitamente, un modelo alternativo.

A mayores, el Libro de Gracián también está interviniendo en los debates concretos del reinado de Juan II. Como ya mencionamos, estos debates giran en torno a la figura del privado y, concretamente, en torno a la figura de Álvaro de Luna. En este sentido, cabe recordar el enfrentamiento del arzobispo Diego de Anaya con el privado del rey, de forma que al menos ciertos aspectos del texto pueden leerse como una crítica indirecta al condestable. Pero quizás más relevante para el tema que nos ocupa aquí -la definición y construcción discursiva del príncipes- es la relación que se establece en el texto entre la corrupción del príncipe y la figura del privado. Al contrario que con el príncipe, cuya importancia y funciones se reconocen en todo momento, los aspectos positivos de privados y consejeros están totalmente ausentes.

No se trata únicamente de que la figura del privado o consejero sea una figura negativa, sino que está directamente relacionada con la corrupción moral de los príncipes y 
las exacciones y saqueos sobre el pueblo. Así, el texto presenta un relato de decadencia moral en el cuál los príncipes se alejan de sus funciones debido a la "novedad" de los privados:

Fijo, al comienço que los prínçipes fueron ordenados t puestos en el pueblo, por quanto muy grand cargo $t$ trabajo les era encomendado, fue por el pueblo ordenado que oviesen renta, por tal que oviesen su mantenimiento [et] proveimiento nesçesario $t$ convenible, por tal que biviesen sirviendo a Dios $t$ faziendo al pueblo que lo amasen $t$ temiesen, $t$ buenas costunbres pusiesen $\mathrm{t}$ mantoviesen (...). $\mathrm{t}$ algunos prínçipes al començamiento ordenavan tan bien su comer, bever, vestir, despender $t$ su dar a nesçesidad $t$ a provecho, que avían abasto de lo que así levavan en todas las cosas que les eran menester, tal manera que el pueblo era conservado $t$ guardado en justiçia t non dapnificado nin disipado. Por la qual cosa los tales prínçipes eran agradables a Dios $t$ a los pueblos (...) Cresçieron después, fijo, en los prínçipes, errores t pecados. Et acaesçió en el pueblo novedad de prínçipes $t$ falsos privados $t$ consejeros. $t$ corronpida fue en los prínçipes justiçia, prudençia, abstenençia, tenprança $t$ caridad t otras vertudes $t$ la ordenaçión sobredicha. Por lo qual, las sus rentas propias que les eran asignadas por voluntad del pueblo diéronlas a los sus malos privados, falsos $t$ lisonjeros, por arterías t engannos que con lo prinçipes t reyes traxeron. Por la qual razón los prínçipes echaron sobre el pueblo tributos nuevos, llevándolos por fuerça de los pobladores de la tierra, $\mathrm{t}$ tan grandes $\mathrm{t}$ crueles tributos, que el pueblo padesçe en tantos dannos, que son a Dios dados grandes clamores (...) (SATORRE, 1981-1983, p. 108-109).

De esta forma, lo político se construye en un contraste entre el príncipe sin privados, que se caracteriza por ser capaz de guardar la justicia, agrada a Dios, no daña al pueblo, sino que lo guarda de manera justa, y el príncipe pecador que, rodeado de privados, pierde las virtudes y daña al pueblo por medio de tributos abusivos. La figura del privado, entonces, se presenta como una figura peligrosa, que corrompe el orden político. Esto encaja en las discusiones en torno a la "privanza" durante el reinado de Juan II, presentando una idea de rey que no encaja con la realmente existente en ese momento, que se caracteriza por una concentración de poder en las manos del privado, Álvaro de Luna.

Un elemento más a tener en cuenta es la idea de tiranicidio, que se presenta durante el viaje de Gracián, y cuya defensa se pone en boca de un musulmán. Como ya vimos, el término "tirano" se empleaba para caracterizar a Álvaro de Luna. En este sentido, la defensa del tiranicidio ${ }^{21}$ en el texto puede entenderse como una forma de legitimar la resistencia contra aquel, precisamente debido a los grandes males que causa en el pueblo, ya que, como

\footnotetext{
${ }^{21}$ Véanse Nieto Soria (2017) y Serverat (2005).
} 
afirma el personaje musulmán: "por el pecado del príncipe, Dios da plaga en el pueblo, et, por el pecado del pueblo, Dios da plaga en el príncipe" (SATORRE, 1981-1983, p. 153-155).

La idea de príncipe en el Libro de Gracián se construye en relación a las nociones que circulan en la Baja Edad Media castellana en torno al rey y la monarquía. Por una parte, la visión negativa que se presenta de los príncipes corresponde a una inversión de los modelos idealizados propios de la literatura especular, construyendo una percepción de la realidad del poder que enfatiza su carácter decadente. Además, la noción de príncipe se complementa con su relación con los privados, entendidos como un elemento que conduce a abusos y exacciones injustas al pueblo. Así, el Libro de Gracián resulta ser una intervención en el debate político de su época, esto es, un intento de definir construir una idea de príncipe.

\section{Conclusiones}

A lo largo de este trabajo, hemos ido aproximándonos al Libro de Gracián y sus elementos políticos, buscando insertar el texto en los debates de su época, esto es, destacando algunos de los contextos que pueden servir para comprender la obra. Así, nos parece que el pensamiento político del texto es producto, al menos en parte, de una situación política de conflicto, en la que Álvaro de Luna juega un papel como antagonista de los intereses que representa el texto. En este sentido, la obra se puede entender como una forma de pensar el mundo político de su momento de forma crítica, buscando deslegitimar al privado de Juan II. Hay diversos elementos que apuntan a esto:

a) El carácter crítico con la sociedad de su época que aparece a lo largo del relato, en el que no sólo hay una reflexión general sobre prelados, príncipes o privados, sino también un viaje, en el que Gracián presencia toda clase de abusos.

b) La procedencia del texto de los círculos sociales de Diego de Anaya, de forma que este funciona como un autor-promotor, lo que nos ayuda a entender el texto como un ataque a Álvaro de Luna, quién estaba enfrentado con el arzobispo.

c) La aproximación teórica realizada, que nos orienta a entender el texto como situado en relación a las intenciones, debates y lenguajes conceptuales de su época. En especial, los debates en torno a la figura de Álvaro de Luna. 
d) La noción de príncipe que se presenta en el texto, que puede entenderse también como una forma de participar en la imaginación política de su momento, al enfatizar los aspectos negativos del rey, causados por la existencia de privados.

\section{REFERENCIAS BIBLIOGRÁFICAS}

CANNING, Joseph. A history of medieval political thought, 300-1450. Londres y Nueva York: Routledge, 2003.

DÍAZ MARCILLA, Francisco. El hilo luliano de la madeja cultural castellana medieval. Nuevos aportes al lulismo medieval laico y religioso. En: HIGUERA RUBIO, José (ed.). Knowledge, contemplation and Iullism. Contributions to the lullian session at the SIEPM Congress - Freising, August 20-25, 2012. Turnhout: Brepols, 2015, p. 165-190.

FOUCAULT, Michel. What is an author? En: FOUCAULT, Michel; BOUCHARD, Donald F. (ed.) Language, counter-memory and practice. Selected essays and interviews. Ithaca: Cornell University Press, 1977, p. 113-138.

GÓMEZ REDONDO, Fernando. Historia de la prosa medieval castellana. vol. III: Los orígenes del humanismo. El marco cultural de Enrique III y Juan II. Madrid: Cátedra, 2002.

GUADALAJARA, José. Álvaro de Luna y el Anticristo. Imágenes apocalípticas en don íñigo López de Mendoza. Revista de Literatura Medieval. v. 2, 1990, p. 183-206

MÁR JÓNSSON, Einar. Les miroirs aux princes sont-ils un genre littéraire. Médiévales, v. 51, 2006, p. 153-166.

MONSALVO ANTÓN, José María. El conflicto 'nobleza frente a monarquía' en el contexto de las transformaciones del estado en la Castilla Trastámara. Reflexiones críticas. En: JARA FUENTE, José Antonio (coord.). Discurso político y relaciones de poder: ciudad, nobleza y monarquía en la Baja Edad Media. Madrid: Dykinson, 2017, p. 89-287.

MONSALVO ANTÓN, José María. Diego de Anaya (1357-1437) y su tiempo. Aristócrata, obispo, diplomático y humanista. En: PENA GONZÁLEZ, Miguel Anxo; RODRÍGUEZ-SAN PEDRO BEZARES, Luis E. (coords.) La universidad de Salamanca y el pontificado en la Edad Media. Salamanca: Publicaciones Universidad Pontificia, 2014, p. 117-254.

NIETO SORIA, José Manuel. Álvaro de Luna tirano. Opinión pública y conflicto político en la Castilla del siglo XV. Imago Temporis. Medium Aevum, v. 9, 2017, p. 488-507.

NIETO SORIA, José Manuel. La nobleza y el 'poderío real absoluto' en la Castilla del siglo XV. Cahiers d'études hispaniques médiévales, v. 25, 2002, p. 237-254.

NOGALES RINCÓN, David. Los espejos de príncipes en Castilla (siglos XIII-XV): un modelo literario de la realeza bajomedieval. Medievalismo. Boletín de la Sociedad Española de Estudios Medievales, v. 16, 2006, p. 9-39.

POCOCK, John G. A. Political thought and history: essays in theory and method. Cambridge: Cambridge University Press, 2009. 
SATORRE, José J. La novela moral de Gracián (Un texto inédito del siglo XV). Studia Lulliana. v. 24, n. 2, 1980, p. 165-210.

. La novela moral de Gracián (continuación). Studia Lulliana. v.25, n. 1, 1981-1983, p. 83-165. . La novela moral de Gracián (conclusión). Studia Lulliana. v. 26, n. 2, 1986, p. 165-251.

SERVERAT, Vincent. Une légitimation islamique de la résistance au tyranne au temps de Jean II de Castille: "Semblanza y tratado de Gracián " (chapitre VIII). Cahiers d'études hispaniques médiévales, v. 28, 2005, p. 391-404.

SKINNER, Quentin. Visions of politics. vol. 1: regarding method. Cambridge: Cambridge University Press, 2002.

STRAYER, Joseph. Sobre los orígenes medievales del estado moderno. Barcelona: Ariel, 1981.

TRÍAS MERCANT, Sebastiá. La ética luliana en el 'Félix de les meravelles'. Studia Lulliana. v. 13, n. 2-3, 1969, p. 113-132.

VÁZQUEZ JANEIRO, Isaac. Gracián: un 'Félix' castigliano del secolo XV. Una ricerca sull'innominato autore. Annali dell'Instituto Universitario Orientale. Sezione Romanza, v. 34, n. 1, 1992, p. 295-337.

WATTS, John. The making of polities: Europe, 1200-1300. Cambridge: Cambridge University Press, 2009. 